\title{
Article
}

\section{Finger-Actuated Microneedle Array for Sampling Body Fluids}

\author{
Misagh Rezapour Sarabi ${ }^{1}\left(\mathbb{D}\right.$, Abdollah Ahmadpour ${ }^{2}$, Ali K. Yetisen ${ }^{3}$ and Savas Tasoglu ${ }^{1,4,5,6,7, * \mathbb{D}}$ \\ 1 Department of Mechanical Engineering, Koç University, Sariyer, 34450 Istanbul, Turkey; msarabi19@ku.edu.tr \\ 2 Department of Mechanical Engineering, Isfahan University of Technology, Isfahan 84156-83111, Iran; \\ a.ahmadpour@me.iut.ac.ir \\ 3 Department of Chemical Engineering, Imperial College London, London SW7 2AZ, UK; \\ a.yetisen@imperial.ac.uk \\ 4 Koc University Research Center for Translational Medicine, Koç University, Sariyer, 34450 Istanbul, Turkey \\ 5 Center for Life Sciences and Technologies, Bogazici University, Bebek, 34342 Istanbul, Turkey \\ 6 Boğaziçi Institute of Biomedical Engineering, Boğaziçi University, Çengelköy, 34684 Istanbul, Turkey \\ 7 Koç University Arçelik Research Center for Creative Industries (KUAR), Koç University, Sariyer, \\ 34450 Istanbul, Turkey \\ * Correspondence: stasoglu@ku.edu.tr
}

Citation: Sarabi, M.R.; Ahmadpour, A.; Yetisen, A.K.; Tasoglu, S. Finger-Actuated Microneedle Array for Sampling Body Fluids. Appl. Sci. 2021, 11, 5329. https://doi.org/ 10.3390/app11125329

Academic Editor: Mehdi Jangi

Received: 13 May 2021

Accepted: 5 June 2021

Published: 8 June 2021

Publisher's Note: MDPI stays neutral with regard to jurisdictional claims in published maps and institutional affiliations.

Copyright: (c) 2021 by the authors. Licensee MDPI, Basel, Switzerland. This article is an open access article distributed under the terms and conditions of the Creative Commons Attribution (CC BY) license (https:/ / creativecommons.org/licenses/by/ $4.0 /)$.

\begin{abstract}
The application of microneedles (MNs) for minimally invasive biological fluid sampling is rapidly emerging, offering a user-friendly approach with decreased insertion pain and less harm to the tissues compared to conventional needles. Here, a finger-powered microneedle array (MNA) integrated with a microfluidic chip was conceptualized to extract body fluid samples. Actuated by finger pressure, the microfluidic device enables an efficient approach for the user to collect their own body fluids in a simple and fast manner without the requirement for a healthcare worker. The processes for extracting human blood and interstitial fluid (ISF) from the body and the flow across the device, estimating the amount of the extracted fluid, were simulated. The design in this work can be utilized for the minimally invasive personalized medical equipment offering a simple usage procedure.
\end{abstract}

Keywords: microneedles; microfluidics; finite-element method; fluid mechanics; wearables

\section{Introduction}

Since their inception in 1976 as a drug delivery device [1] until 2020 where they were regarded as one of the top 10 emerging technologies [2], microneedles (MNs) have presented many advantages in injection processes, including minimizing insertion pain and reducing tissue damage and controlled drug delivery as compared to the conventional needle technologies. With different geometries and designs [3,4], such as solid, hollow, coated, or biodegradable [5] needle types in the scale of micrometers and nanometers [6], microneedle arrays (MNAs) can be fabricated with numerous methods such as 3D printing $[7,8]$. MNAs can be inserted into a target area, even within the depth of skin epidermis and thus they have emerging biomedical applications in drug delivery systems [9-12] with the capability of programmed deliveries of drug doses for multiple-injection therapies such as vaccination [13], sampling interstitial fluid (ISF) [14,15] biomarker detection [16], enhanced wound healing [17], fertility control [18], point-of-care (POC) setups and diagnostic tests [19,20], DNA extraction [21,22], cancer therapy [23], and force sensing [24].

Computational methods that allow for simulation of the experiment or setup conditions for prognosticating their behaviors with conceivable problems or using artificial intelligence techniques for post analysis of data [25] have also emerged in MNs. Finite element analysis was used for simulating the transdermal drug delivery process of MNs into the skin in order to study the effect of penetration depth and number of MNs on each patch, demonstrating increasing proportionality of delivered drugs with both factors [26]. To study the Von Mises stress, an index of yield or fracture in materials, in a design of 
MNAs with triangular-shaped bases, researchers demonstrated that the MNs in the middle part of the array were under more stress and displacement [27]. In addition, in a microfluidic system with MNs including a drug reservoir, displacement of MNs was modeled and simulated [28]. Structural analysis of MNs was also reported [29]. In another study using finite element analysis (FEM), the bending procedure and the distribution of the loaded stress on the MNs during their insertion into the skin were simulated [30]. A circular flange was introduced to the base of each $\mathrm{MN}$ as the results of the simulation demonstrated that MNs were most likely to fail in the area between the needle body and the supporting array because of stress concentration in this spot. Furthermore, finite element analysis was used to study modeling the surface concentration profiles of the delivered drug in a MN design with hemispherical convexities on the needle for the aim of increasing drug delivery flux [31].

In this study, a microneedle array (MNA) integrated with a microfluidic channel chip was designed to extract and sample body fluids powered by finger press, featuring an easy procedure that can be applied by the user without need for the presence of healthcare workers. This design contains an array of $100 \mathrm{MNs}$ with co-centric circular holes for fluid transport. The target fluid, for example blood or interstitial fluid (ISF), can be extracted by the power created by pressing with fingers followed by flowing in the microfluidics and finally being collected in a reservoir. The process of fluid flow and its transport across the device and its collection was modeled and simulated with a finite element model. The amount of the extracted fluid was studied with the simulation along with the generation of the curves for mass flow rate at the reservoir.

\section{Methods}

\subsection{Design of the Device}

The microneedle array (MNA) with a microfluidic chip was designed to be powered by pressing with finger (Figure 1a). The device was designed with Dassault Systèmes (3DS) SolidWorks computer-aided design (CAD) and computer-aided engineering (CAE). The microfluidic chip was designed as a box with the dimensions of length $(\mathrm{L}=40 \mathrm{~mm})$, width $(\mathrm{W}=20 \mathrm{~mm})$, and height $(\mathrm{H}=9.3 \mathrm{~mm})$ (the final height of the device with the MNA integrated is $10 \mathrm{~mm}$ ). The design of the microfluidic system (Figure 1b) included a deformable dome-shaped chamber for mechanical pressure input by pressing with finger to provide a force to guide the fluid from the MNA inlet to the reservoir outlet. The MNA was connected to a duct that guided the extracted fluid to the reservoir via the channels with a diameter of $2 \mathrm{~mm}$. The designed MNs and their geometry are shown in Figure 1c.

For designing the MNs, experimentally reported MNs with applications in sampling or extraction of body fluids such as ISF, blood, and glucose detection were reviewed, and the geometrical properties of the MNs, which included the height of the needle, its base diameter, the needle tip diameter, and the distance between the MNs in the case of MNAs, along with the efficiency of the reported investigation, are shown in Table 1. To choose a convenient design for the MNs, we used the reported data to create chart boxes of the data (Table 2). The table shows the box chart for the reported MN height in micrometers with most of the reported heights of MN to be in the range of 400 to $800 \mu \mathrm{m}$. Commercial MN vaccine delivery systems mostly have a height of $600 \mu \mathrm{m}$ [32]. As a result, it is appropriate to design a MN with a height in this domain. The MNs in this work have a needle height of $\mathrm{H}_{\mathrm{MN}}=700 \mu \mathrm{m}$. According to the data of the base diameter of the previously reported MNs (Table 1), the diameter of the needle base was designed as $B=300 \mu \mathrm{m}$. The diameter of the needle tip was designed to be $\mathrm{D}=80 \mu \mathrm{m}$. The box charts for the number of the MNs in an array and the interspacing between the MNs are demonstrated in Table MNA in the present work was designed in an area of $6 \times 6 \mathrm{~mm}$, consisting of 100 microneedles (MNs) with interspacing of $600 \mu \mathrm{m} \mathrm{MNs}$ ' center-to-center distance. 

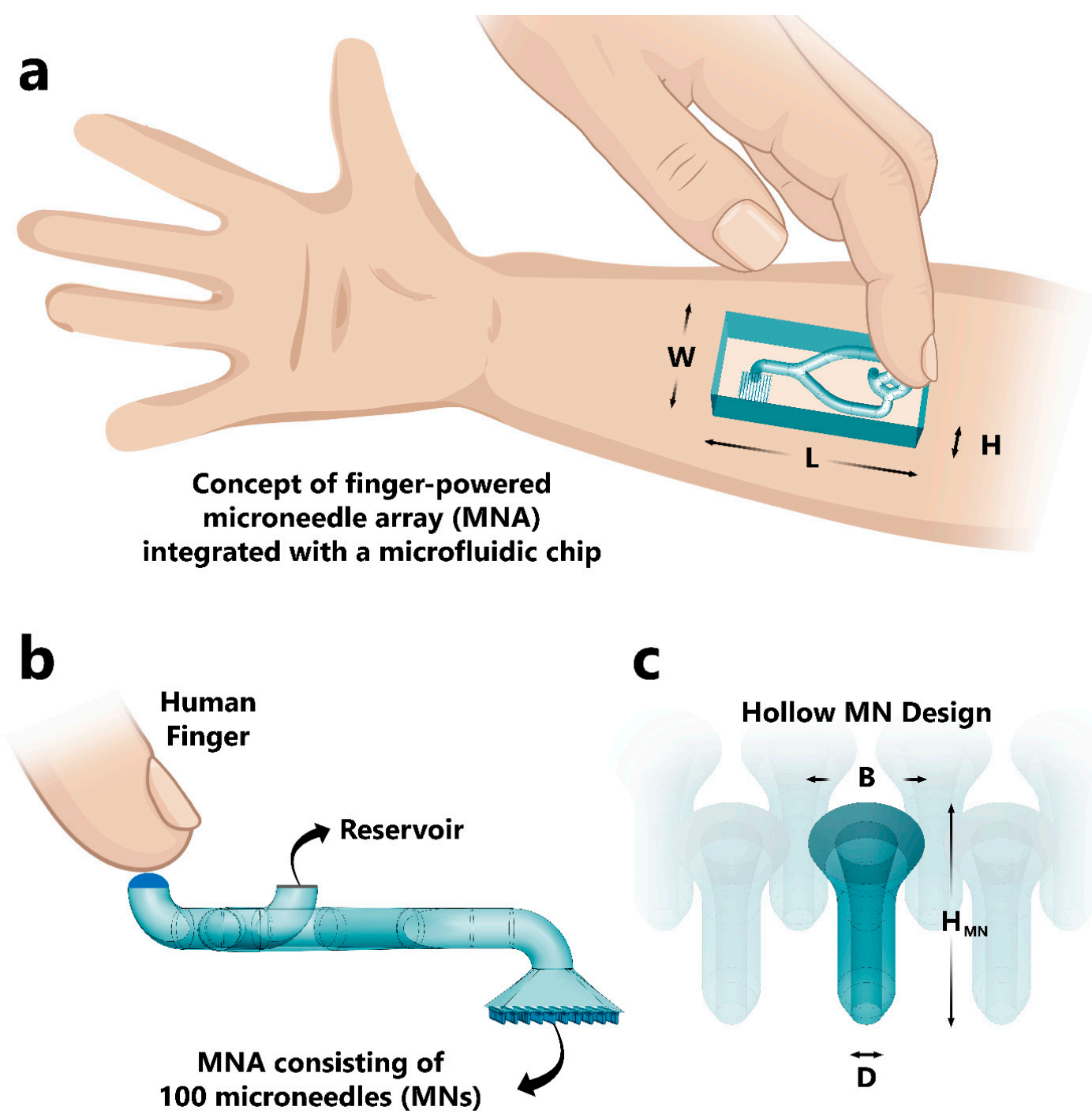

Figure 1. Concept of finger-powered microneedle array (MNA) integrated with a microfluidic chip for the aim of extracting body fluid samples. (a) The device is designed to be powered by pressing with a finger, hence enabling a simple approach that the user can sample easily without need for healthcare workers, as shown schematically. The dimensions of the designed device are as follows: length, $\mathrm{L}=40 \mathrm{~mm}$; width, $\mathrm{W}=20 \mathrm{~mm}$; and height, $\mathrm{H}=9.3 \mathrm{~mm}$. (b) The design of the channels of the chip, in which the array of 100 microneedles (MNs) is connected to a duct that guides the extracted fluid to the reservoir via the channels by means of pressing with a finger. (c) The geometry of each MN, consisting of a hollow design with the following dimensions: height, $\mathrm{H}_{\mathrm{MN}}=700 \mu \mathrm{m}$; diameter of the needle tip, $\mathrm{D}=80 \mu \mathrm{m}$; and the diameter of the needle base, $\mathrm{B}=300 \mu \mathrm{m}$.

On the other hand, the required force for penetration of the microneedles into the skin can be easily provided by the user. Precise measurements of the required insertion force for MNs were previously reported, showing that an amount in the range of 0.03 to $0.4 \mathrm{~N}$ per $\mathrm{MN}$ is sufficient for piercing the stratum corneum (SC) and insertion into the skin $[16,33,34]$, which is low enough to allow insertion by hand [34]. In addition, according to the experimental literature presented in the Table 2, MNs with similar design to that of the present work adequately penetrated human skin, demonstrating potency of proposed MNs for penetration. 
Table 1. Geometrical properties of experimentally reported microneedle arrays (MNAs) with applications in sampling or extraction of body fluids.

\begin{tabular}{|c|c|c|c|c|c|c|c|c|}
\hline$\#$ & Aim of the Work & MN Height & $\begin{array}{l}\text { MN Base } \\
\text { Diameter }\end{array}$ & $\begin{array}{l}\text { MN Tip } \\
\text { Diameter }\end{array}$ & $\begin{array}{l}\text { Number of } \\
\text { MNs in } \\
\text { the Array }\end{array}$ & $\begin{array}{l}\text { Interspacing } \\
\text { between } \\
\text { MNs }\end{array}$ & $\begin{array}{c}\text { Extraction or } \\
\text { Sampling Amount of } \\
\text { Each MN }\end{array}$ & Ref. \\
\hline 1 & $\begin{array}{l}\text { Glucose } \\
\text { detection }\end{array}$ & $400 \mu \mathrm{m}$ & - & - & 1 & - & 4 to $7 \mathrm{mM}$ & [35] \\
\hline 2 & $\begin{array}{l}\text { Skin penetration } \\
\text { of MNs }\end{array}$ & $600 \mu \mathrm{m}$ & $300 \mu \mathrm{m}$ & - & $4,9,16$ & 30 to $600 \mu \mathrm{m}$ & - & [33] \\
\hline 3 & Blood extraction & $1800 \mu \mathrm{m}$ & - & $120 \mu \mathrm{m}$ & 1 & - & $20 \mu \mathrm{L}$ & [36] \\
\hline 4 & $\begin{array}{l}\text { Skin interstitial } \\
\text { fluid (ISF) } \\
\text { extraction }\end{array}$ & $600 \mu \mathrm{m}$ & $300 \mu \mathrm{m}$ & - & 121 & $100 \mu \mathrm{m}$ & $\approx 0.02 \mathrm{mg}$ & [37] \\
\hline 5 & $\begin{array}{l}\text { Rhodamine B } \\
\text { (RhB), a tracer } \\
\text { dye, absorption } \\
\text { using hydrogel } \\
\text { MNs }\end{array}$ & $700 \mu \mathrm{m}$ & - & - & 6 & - & $\approx 4.2 \mathrm{mg} / \mathrm{L}$ & [38] \\
\hline 6 & ISF extraction & $\begin{array}{l}1000 \mu \mathrm{m} \\
\text { and } \\
1500 \mu \mathrm{m}\end{array}$ & - & - & 16,32 & - & $\begin{array}{c}\text { Flat profile geometry: } \\
0.028 \pm 0.021 \mu \mathrm{L} / \mathrm{min} \\
\text { Concave profile } \\
\text { geometry: } \\
0.053 \pm 0.040 \mu \mathrm{L} / \mathrm{min} \\
\text { Convex profile } \\
\text { geometry: } \\
0.020 \pm 0.013 \mu \mathrm{L} / \mathrm{min} \\
\text { Bevel profile geometry: } \\
0.028 \pm 0.029 \mu \mathrm{L} / \mathrm{min}\end{array}$ & [39] \\
\hline 7 & $\begin{array}{l}\text { Collecting } \\
\text { phosphate- } \\
\text { buffered saline } \\
\text { (PBS), a liquid } \\
\text { model for ISF }\end{array}$ & $1000 \mu \mathrm{m}$ & $1000 \mu \mathrm{m}$ & - & 21 & $3000 \mu \mathrm{m}$ & $\approx 7.15 \mathrm{mg}$ & [40] \\
\hline 8 & $\begin{array}{l}\text { Skin ISF } \\
\text { extraction }\end{array}$ & $\begin{array}{l}250 \mu \mathrm{m}, \\
450 \mu \mathrm{m}, \\
\text { and } \\
650 \mu \mathrm{m}\end{array}$ & $200 \mu \mathrm{m}$ & $10 \mu \mathrm{m}$ & 5 & - & $0.46 \pm 0.52 \mu \mathrm{L}$ & [15] \\
\hline 9 & $\begin{array}{l}\text { Dermal ISF } \\
\text { extraction }\end{array}$ & $\begin{array}{l}1000 \mu \mathrm{m}, \\
1500 \mu \mathrm{m}, \\
\text { and } \\
2000 \mu \mathrm{m}\end{array}$ & - & - & 5 & - & $\begin{array}{c}4 \mu \mathrm{L} \text { (Humans) } \\
12 \mu \mathrm{L} \text { (Rats) }\end{array}$ & [41] \\
\hline 10 & $\begin{array}{l}\text { Detection of } \\
\text { drugs and } \\
\text { glucose }\end{array}$ & $600 \mu \mathrm{m}$ & $300 \mu \mathrm{m}$ & - & 361 & $50 \mu \mathrm{m}$ & $\begin{array}{l}\text { Caffeine detection: } \\
\approx 0.25 \mu \mathrm{g} / \mathrm{mL} \\
\text { Glucose detection: } \\
\approx 0.022 \mathrm{nmol} / \mathrm{L} \\
\text { Glucose extraction: } \\
\approx 0.011 \mathrm{nmol} / \mathrm{L}\end{array}$ & [42] \\
\hline 11 & PBS absorption & $550 \mu \mathrm{m}$ & $200 \mu \mathrm{m}$ & - & 225 & $500 \mu \mathrm{m}$ & $\approx 200 \%$ weight gain & [43] \\
\hline 12 & ISF extraction & $900 \mu \mathrm{m}$ & $280 \mu \mathrm{m}$ & - & 100 & - & $\begin{array}{l}\text { Extraction from } \\
\text { pig skin: } \\
\approx 0.079 \mu \mathrm{L} \\
\text { Extraction from } \\
\text { rat skin: } \\
\approx 0.0382 \mu \mathrm{L}\end{array}$ & [14] \\
\hline 13 & $\begin{array}{c}\text { Detection of } \\
\text { nucleic acid } \\
\text { biomarkers from } \\
\text { skin ISF }\end{array}$ & $550 \mu \mathrm{m}$ & $250 \mu \mathrm{m}$ & - & 49 & $\begin{array}{l}340 \text { and } 400 \\
\mu \mathrm{m}\end{array}$ & $\approx 0.133 \mu \mathrm{L}$ & [44] \\
\hline 14 & ISF extraction & $680 \mu \mathrm{m}$ & $380 \mu \mathrm{m}$ & - & 144 & - & $0.0250 \pm 0.0042 \mathrm{mg}$ & [45] \\
\hline
\end{tabular}


Table 1. Cont

\begin{tabular}{|c|c|c|c|c|c|c|c|c|}
\hline$\#$ & Aim of the Work & MN Height & $\begin{array}{l}\text { MN Base } \\
\text { Diameter }\end{array}$ & $\begin{array}{l}\text { MN Tip } \\
\text { Diameter }\end{array}$ & $\begin{array}{l}\text { Number of } \\
\text { MNs in } \\
\text { the Array }\end{array}$ & $\begin{array}{c}\text { Interspacing } \\
\text { between } \\
\text { MNs }\end{array}$ & $\begin{array}{c}\text { Extraction or } \\
\text { Sampling Amount of } \\
\text { Each MN }\end{array}$ & Ref. \\
\hline 15 & $\begin{array}{l}\text { Dermal ISF } \\
\text { extraction }\end{array}$ & $\begin{array}{l}750 \mu \mathrm{m} \\
\text { and } \\
650 \mu \mathrm{m}\end{array}$ & $\begin{array}{c}100 \mu \mathrm{m} \times \\
70 \mu \mathrm{m} \text { and } \\
50 \mu \mathrm{m} \times \\
150 \mu \mathrm{m}\end{array}$ & $<1 \mu \mathrm{m}$ & 5,9 & - & 8 to $97 \mathrm{~nL}$ & [46] \\
\hline 16 & $\begin{array}{l}\text { Skin ISF } \\
\text { extraction }\end{array}$ & $520 \mu \mathrm{m}$ & - & - & 100 & - & 0.01 to $1 \mu \mathrm{L}$ & [47] \\
\hline 17 & ISF extraction & $1500 \mu \mathrm{m}$ & - & - & 5 & - & 8 to $12 \mu \mathrm{L}$ & {$[48]$} \\
\hline 18 & $\begin{array}{c}\text { Skin ISF } \\
\text { extraction }\end{array}$ & $800 \mu \mathrm{m}$ & $250 \mu \mathrm{m}$ & - & 100 & $450 \mu \mathrm{m}$ & $0.023 \pm 0.004 \mu \mathrm{L}$ & [49] \\
\hline 19 & $\begin{array}{l}\text { Transdermal } \\
\text { detection of } \\
\text { methyl paraoxon } \\
\text { (MPOx) }\end{array}$ & $1500 \mu \mathrm{m}$ & - & - & 9 & $1000 \mu \mathrm{m}$ & 20 to $180 \mu \mathrm{M}$ & [50] \\
\hline 20 & $\begin{array}{l}\text { Detection of skin } \\
\text { ISF biomarkers }\end{array}$ & $800 \mu \mathrm{m}$ & $150 \mu \mathrm{m}$ & - & 16 & - & - & {$[51]$} \\
\hline 21 & $\begin{array}{l}\text { Skin ISF } \\
\text { extraction }\end{array}$ & $\begin{array}{c}1266 \pm 91 \\
\mu \mathrm{m}\end{array}$ & $500 \pm 31 \mu \mathrm{m}$ & - & 100 & - & 0.0125 to $0.075 \mathrm{mg}$ & [52] \\
\hline 22 & Blood extraction & $1800 \mu \mathrm{m}$ & - & $130 \mu \mathrm{m}$ & 1 & - & $31.3 \mu \mathrm{L}$ & {$[53,54]$} \\
\hline
\end{tabular}

Table 2. Box charts of geometrical properties of MNAs reported in Table 1.

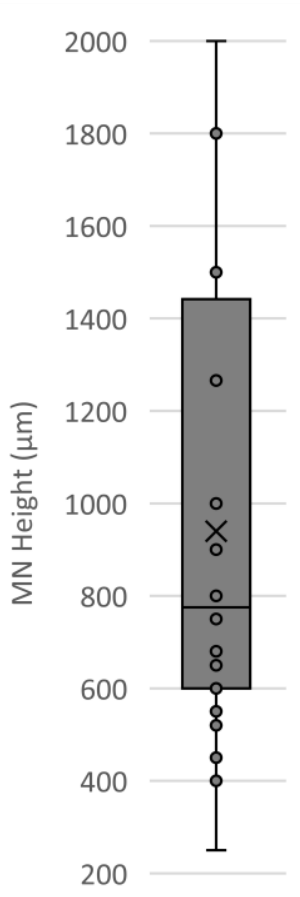

0

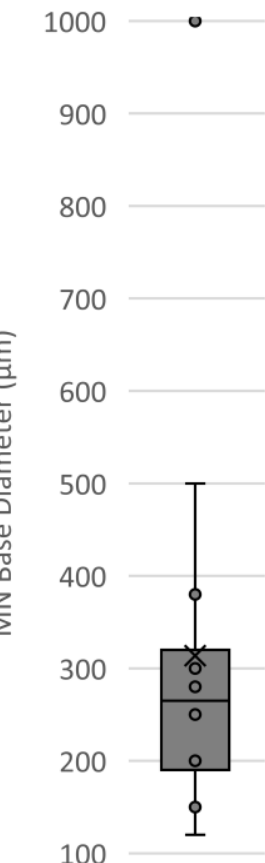

0

\section{0}

300

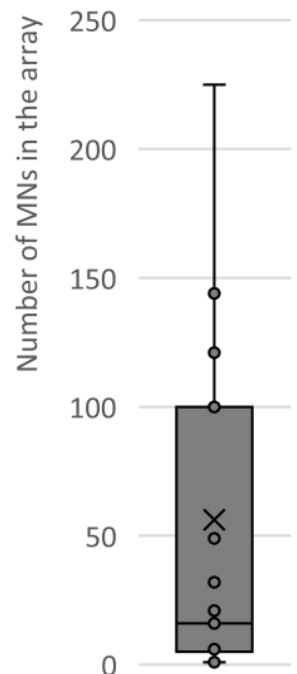

3000

2500

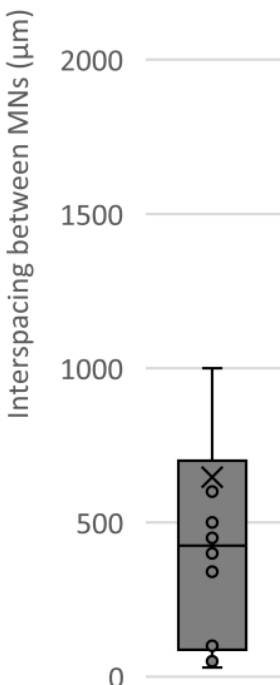

Legend: The dots $(\mathrm{o})$ represent the reported data. The cross marks $(\times)$ represent the mean. The vertical lines inside the boxes represent the median. 


\subsection{Boundary Conditions ( $B C$ s) and Simulation}

The design in this work consists of two inlets and one outlet, which are (i) the input for the mechanical pressure via finger, (ii) the inlet for the target fluid, and (iii) the outlet to the reservoir. For simulating the process of human finger pressing, we used experimental data of a previously designed finger-powered microfluidics device [55]. The average pressure created by human finger pressing is $\approx 4500 \mathrm{~Pa}$. For pressing with a time interval of every $5 \mathrm{~s}$, the following pressure-time function can be developed:

$$
P(t)=2250 \times \cos \left(\frac{2 \pi}{5} \times t\right)+2250
$$

where " $t$ " is time in seconds and " $P$ " is pressure in Pascals. Equation (1) was the base function for the pressure boundary condition $(\mathrm{BC})$ at the finger pressure input. To study the effect of the force input by pressing with fingers, we modified the function of Equation (1) into a version where it defines pressing 5 times faster:

$$
P(t)=2250 \times \cos (2 \pi \times t)+2250
$$

Equation (2) means that the user is pressing the dome-shaped chamber every second. In this equation, " $t$ " is time in seconds and " $P$ " is pressure in Pascals. Human blood was chosen as the first target fluid, aimed to be collected with the designed device. Blood is a non-Newtonian fluid in which the viscosity has been reported to be modeled with several mathematical equations [56]. The power-law model (Equation (3)) was used for the viscosity equation in the simulation:

$$
\mu=k \dot{\gamma}^{n-1}
$$

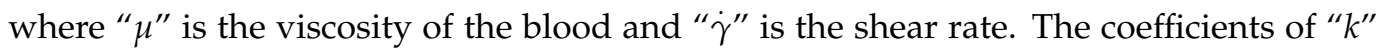
and " $n$ " for blood are 0.42 and 0.61 , respectively $[56,57]$. In addition, the blood density was defined as an amount equal to $1060 \mathrm{~kg} . \mathrm{m}^{-1}$. High-resolution blood flow velocity in the human finger was reported [58] with measurement of arterial blood flow velocities ranging from 0.049 to $0.19 \mathrm{~m} \cdot \mathrm{s}^{-1}$, and venous blood flow velocity in the range of 0.015 to $0.071 \mathrm{~m} . \mathrm{s}^{-1}$. Moreover, the blood flow rate in the arm at rest was reported to be $0.21 \pm 0.04 \mathrm{~L} \cdot \mathrm{min}^{-1}$ [59]. In addition, the amounts of blood pressure in the human arms in sitting and supine position were reported [60], with systolic blood pressure (SBP) $135.5 \pm 24.0 \mathrm{mmHg}$ and diastolic blood pressure (DBP) $79.2 \pm 9.7 \mathrm{mmHg}$ for sitting position and amounts of $\mathrm{SBP}=145.0 \pm 23.2 \mathrm{mmHg}$ and $\mathrm{DBP}=84.1 \pm 9.0 \mathrm{mmHg}$ for supine position. On the other hand, the normal human heart rate at rest is in the range of 60 to 100 beats per minute [61,62]. Taking 80 beats per minute with SBP of $135.5 \mathrm{mmHg}(\approx 18,000 \mathrm{~Pa})$ and DBP of $79.2 \mathrm{mmHg}$ $(\approx 10,000 \mathrm{~Pa})$ as the average amounts, we were able to derive an equation of blood pressure in the vessels:

$$
P(t)=4000 \times \cos \left(\frac{13 \pi}{5} \times t\right)+14000
$$

where " $t$ " is time in seconds and " $P$ " is pressure in Pascals. Equation (4) and alternatively a simplified constant pressure value were used as the $\mathrm{BC}$ for the blood input. A second series of simulations were performed for ISF collection. The viscosity of the ISF in the literature was reported to be in the range between 1.2-1.5 $\times 10^{-3}$ Pa.s [63] and $3.5 \times 10^{-3}$ Pa.s [64]. In this work, an average amount of $2.5 \times 10^{-3}$ Pa.s was used. In addition, the density of ISF was reported to be $1000 \mathrm{~kg} \cdot \mathrm{m}^{-3}$ [64]. The input BC for ISF was defined with ISF pressure, which is in the range of -0.5 to $-8.0 \mathrm{mmHg}$ [63], with the negative sign attributing to the action of lymphatics [65]. An average value of $4 \mathrm{mmHg}$ was utilized in the simulation. Additionally, the $\mathrm{BC}$ for the reservoir for all the cases was set to be pressure of zero. The simulation of the fluid transport across the designed device was performed via finite element analysis, generating the flow curves at the reservoir outlet along with pressure and velocity gradients across the device. The physical time of $5 \mathrm{~s}$ was used as the study time in 
all simulation cases, as the highest amount of period time among the utilized trigonometric equations was $5 \mathrm{~s}$. In total, 6 different cases were studied with the simulation (Table 3).

Table 3. The simulated cases of the present study for two different fluids and various boundary conditions (BCs).

\begin{tabular}{ccccc}
\hline Case & Target Fluid & (Pressure Input by Finger) & $\begin{array}{c}\text { BC 2 } \\
\text { (Reservoir) }\end{array}$ & $\begin{array}{c}\text { BC 3 } \\
\text { (Fluid Inlet from MNs) }\end{array}$ \\
\hline 1 & $\begin{array}{c}\text { Human } \\
\text { blood }\end{array}$ & $P(t)=2250 \times \cos \left(\frac{2 \pi}{5} \times t\right)+2250[\mathrm{~Pa}]$ & $P=0$ & $P=135 \mathrm{mmHg}$ \\
\hline 2 & $\begin{array}{c}\text { Human } \\
\text { blood }\end{array}$ & $P(t)=2250 \times \cos (2 \pi \times t)+2250[\mathrm{~Pa}]$ & $P=0$ & $P=135 \mathrm{mmHg}$ \\
\hline 3 & $\begin{array}{c}\text { Human } \\
\text { blood }\end{array}$ & $P(t)=2250 \times \cos \left(\frac{2 \pi}{5} \times t\right)+2250[\mathrm{~Pa}]$ & $P=0$ & $P(t)=4000 \times \cos \left(\frac{13 \pi}{5} \times t\right)+14000[\mathrm{~Pa}]$ \\
\hline 4 & $\begin{array}{c}\text { Human } \\
\text { blood }\end{array}$ & $P(t)=2250 \times \cos (2 \pi \times t)+2250[\mathrm{~Pa}]$ & $P=0$ & $P(t)=4000 \times \cos \left(\frac{13 \pi}{5} \times t\right)+14000[P a]$ \\
\hline 5 & $\begin{array}{c}\text { Interstitial } \\
\text { fluid (ISF) }\end{array}$ & $P(t)=2250 \times \cos \left(\frac{2 \pi}{5} \times t\right)+2250[\mathrm{~Pa}]$ & $P=0$ & $P=4 \mathrm{mmHg}$ \\
\hline 6 & $\begin{array}{l}\text { Interstitial } \\
\text { fluid (ISF) }\end{array}$ & $P(t)=2250 \times \cos (2 \pi \times t)+2250[\mathrm{~Pa}]$ & $P=0$ & $P=4 \mathrm{mmHg}$ \\
\hline
\end{tabular}

\section{Results and Discussion}

The simulation was run for six different cases of Table 3, which included four cases for human blood with various BCs and two cases for ISF with various BCs. Figure 2 shows the created mesh used for the studies. For study case 3 in Table 3 (input function of the heartbeat imitation for the incoming human blood and pressing the mechanical pressure input button every $5 \mathrm{~s}$ ), the field of the velocity in the direction perpendicular to the cross-section of the reservoir channel was visualized in every second (Figure 2a), along with a magnified view for one of the MNs (Figure $2 b$ ). The velocity-time graph for the MNs is shown in Figure 2c. In the fifth second, the velocity reached its maximum amount of around $0.25 \mathrm{~m} . \mathrm{s}^{-1}$, or equivalently $2.436 \mu \mathrm{L} . \mathrm{s}^{-1}$ of human blood output at the reservoir per needle. An experimental setup of an $\mathrm{MN}$ device for collecting mouse blood sample reported an extraction rate of $0.8 \mu \mathrm{L} . \mathrm{s}^{-1}$ per needle [36]. Hence, the present device has the potential to collect samples three times faster.

Figure 3 illustrates the pressure distribution results of the simulation. For ISF and pressing the mechanical pressure input button every $5 \mathrm{~s}$ (study case 5 in Table 3), the pressure distribution in the fifth second is presented in Figure 3a. Figure $3 b$ shows the magnified view of the MNA area. For human blood, the pressure distribution in the device, with input function of the heartbeat imitation and pressing the mechanical pressure input button every 5 s (study case 3 in Table 3), is demonstrated in Figure 3c for every second along with the magnified view of one MN in Figure 3d.

Figure 4 a shows the schematics of the designed device wh referrals to the BCs. For case study 1 in Table 3, which utilized Equation (1) as the BC for the finger pressing dome and average blood pressure of $135 \mathrm{mmHg}$ as the BC for the coming blood from the MNs, the simulation results in mass flow-time curve in the reservoir as shown with red color in Figure $4 \mathrm{~b}$. In the second running of the simulation, the BC for the finger pressure input was changed from Equation (1) to the function given at Equation (2), resulting in the mass flow-time curve in the reservoir, as shown with red color in Figure 4c. Since at least one of the BCs was trigonometric, as expected, both curves that resulted from the simulation were also trigonometric. 

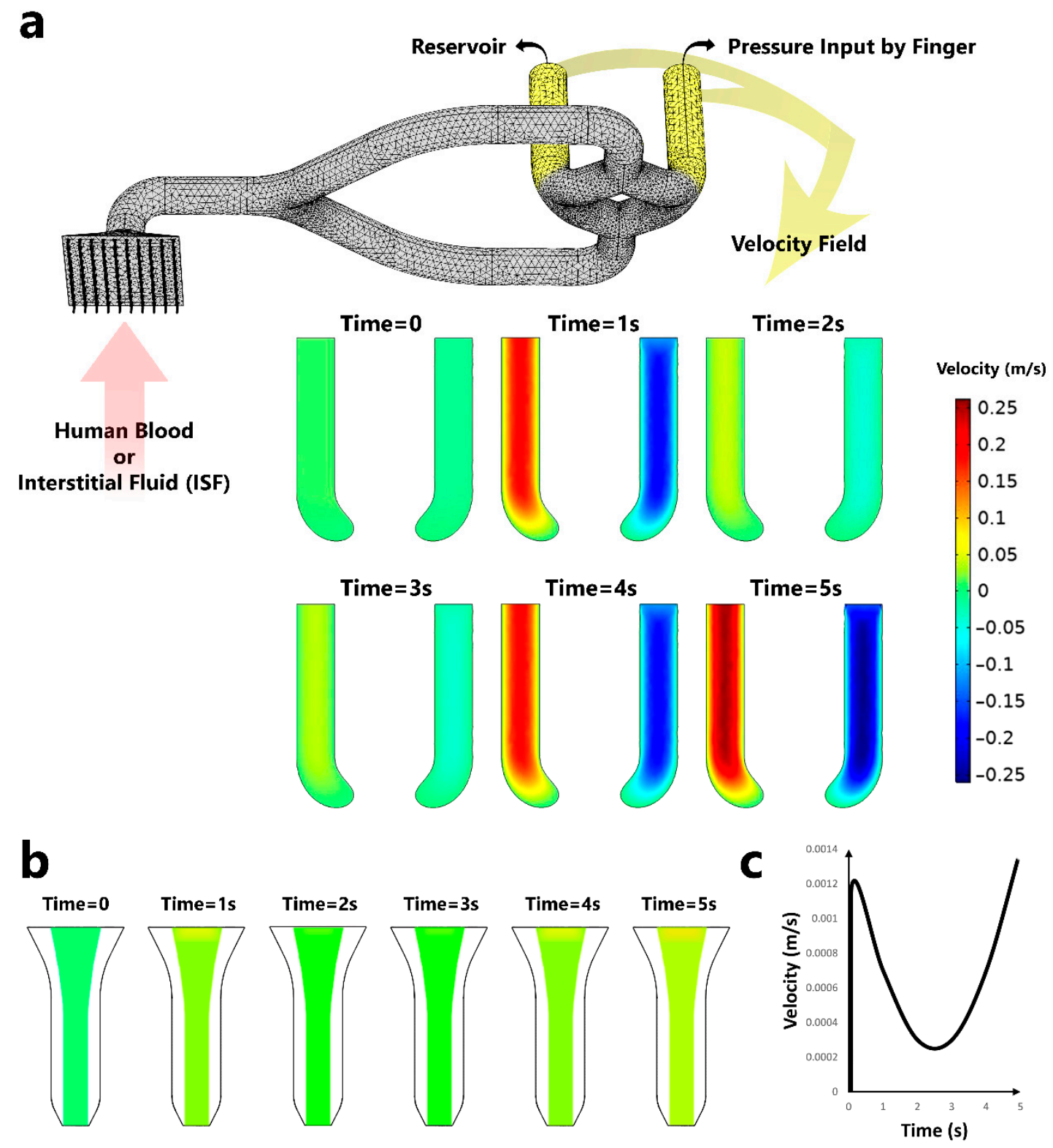

Figure 2. Representation of the created mesh and results of the velocity field. (a) The mesh that was created for the study is represented here. In the highlighted area in yellow, the velocity field results in the direction perpendicular to the cross section of the channels are shown, with the function of the heartbeat imitation for the incoming human blood and pressing the mechanical pressure input button every $5 \mathrm{~s}$ (study case 3 in Table 3). In the fifth second, the velocity reached its maximum amount of around $0.25 \mathrm{~m} . \mathrm{s}^{-1}$. (b) The velocity field for one of the MNs in the patch from time $=0$ to $5 \mathrm{~s}$ and (c) its corresponding velocity-time curve. The color bar shows velocity in $\mathrm{m} / \mathrm{s}$.

The function in Equation (4) was also simulated. Cases 3 and 4 in Table 3 used this equation for the incoming human blood along with slow finger pressure input (Equation (1)) and fast finger pressure input (Equation (2)), respectively. The mass flow-time curves at the reservoir for these two cases are presented in Figures S1 and S2, respectively. Among two states of using a constant pressure for the human blood inlet and heartbeat imitation function of Equation (4), a small amount of difference in the mass flow rate was detected. While the pressure function imitated the heartbeat action and offered a more realistic study condition, the resulting mass flow rate, and hence the amount of the extracted blood, was smaller. 

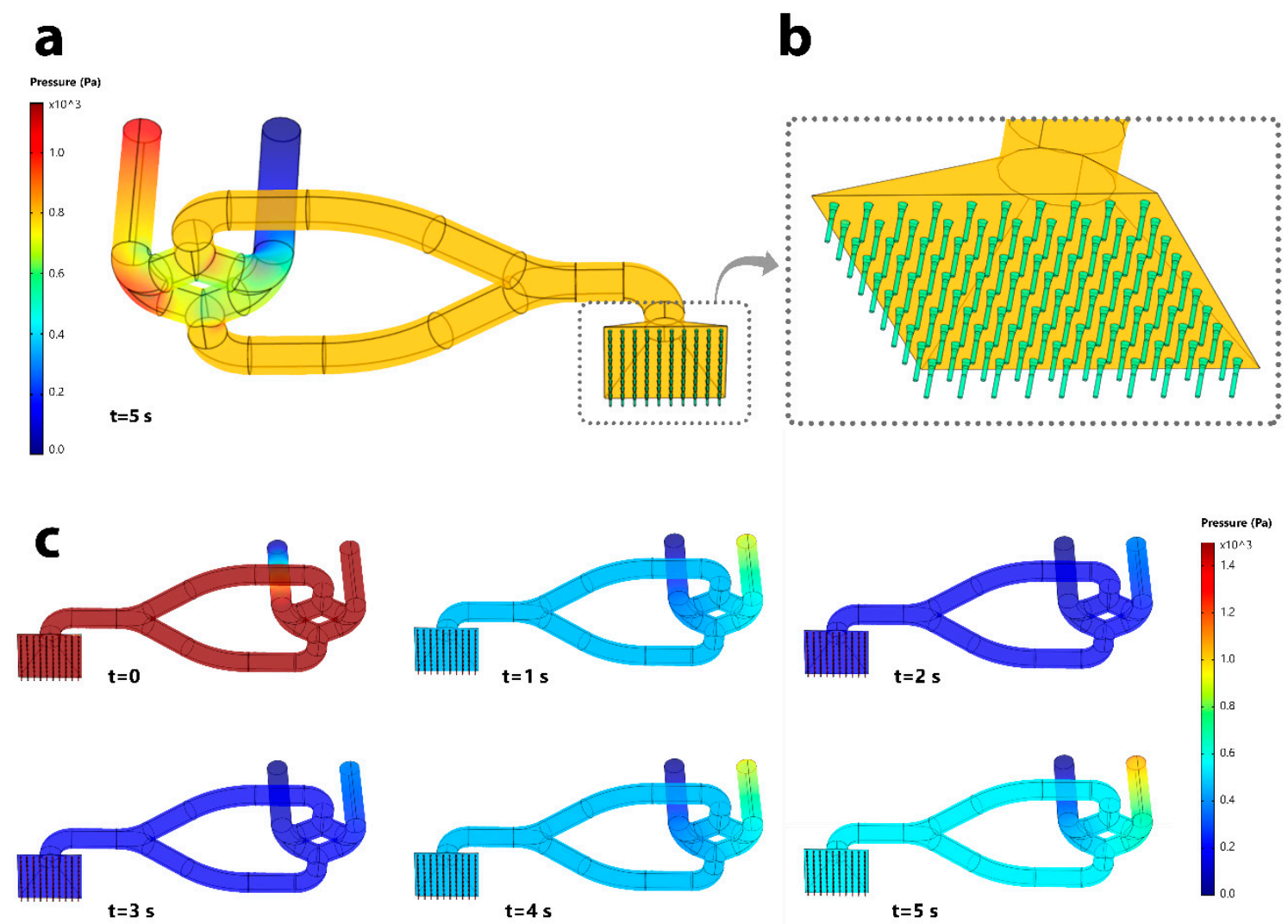

$\mathbf{t}=5 \mathrm{~s}$

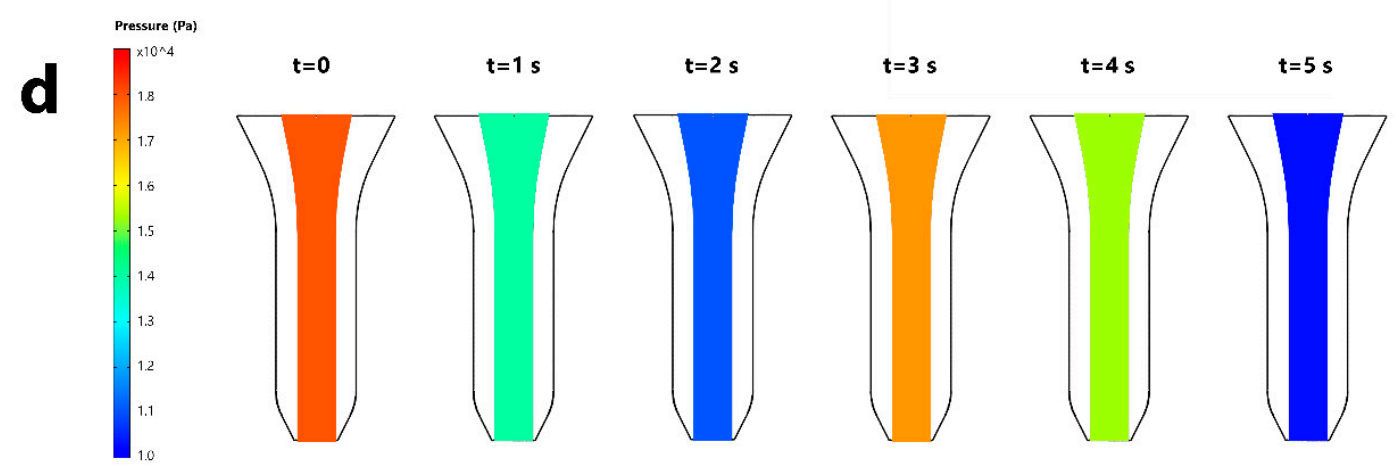

Figure 3. Pressure distribution results. (a) For interstitial fluid (ISF) and pressing the mechanical pressure input button every $5 \mathrm{~s}$ (study case 5 in Table 3), the pressure distribution in the fifth second is represented here along with (b), the magnified view of the microneedle array (MNA) area. (c) Pressure distribution in the device for human blood with input function of the heartbeat imitation and pressing the mechanical pressure input button every $5 \mathrm{~s}$ (study case 3 in Table 3), and (d) the magnified view of one microneedle (MN). All color bars show the amount of pressure in Pascals (Pa).

In another series of simulations, ISF was used as the target fluid. First, Equation (1) was used as the $\mathrm{BC}$ for the finger pressing dome (case 5 in Table 3 ), followed by a second run with Equation (2) (case 6 in Table 3) to study the effect of the force input speed by pressing with fingers. The mass flow curve results at the reservoir are shown with the yellow color in Figure $4 \mathrm{~b}, \mathrm{c}$ for the state of slow (case 5, Table 3) and fast (case 6, Table 3), respectively. 
a
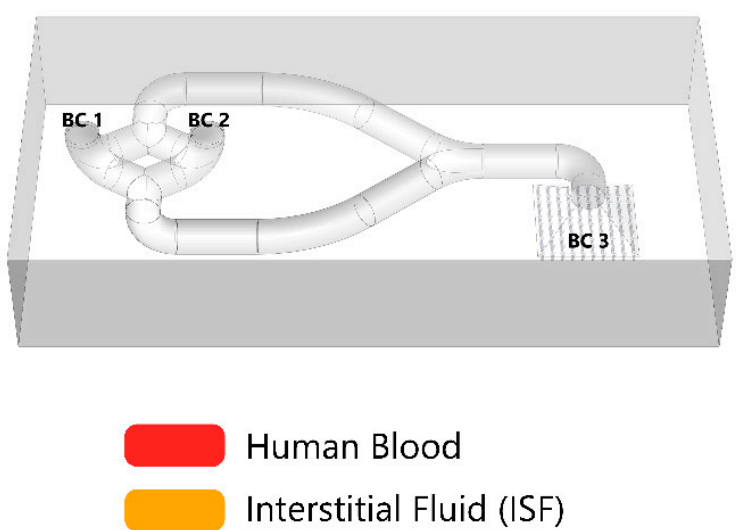

C

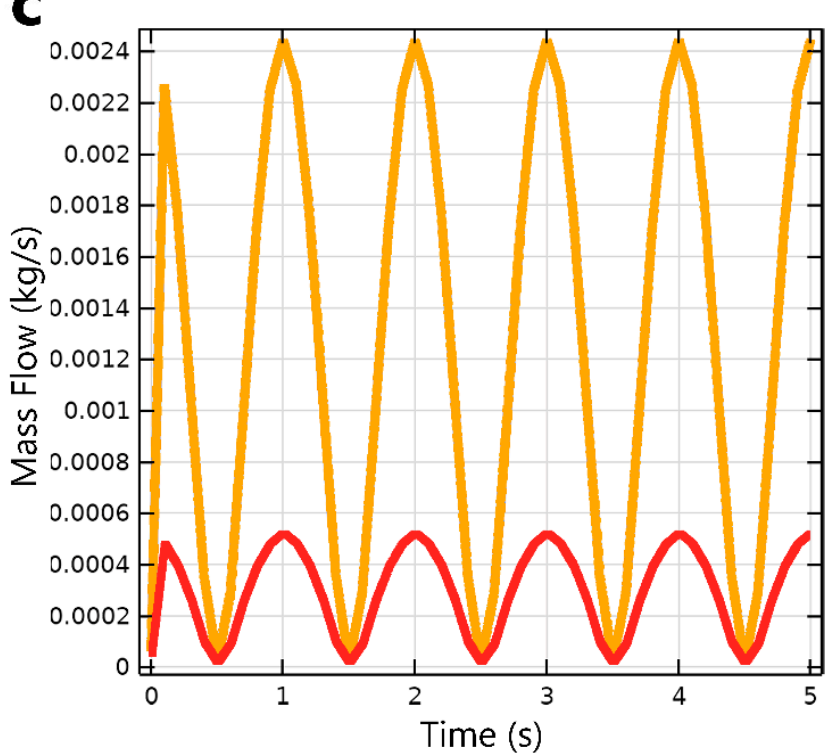

b
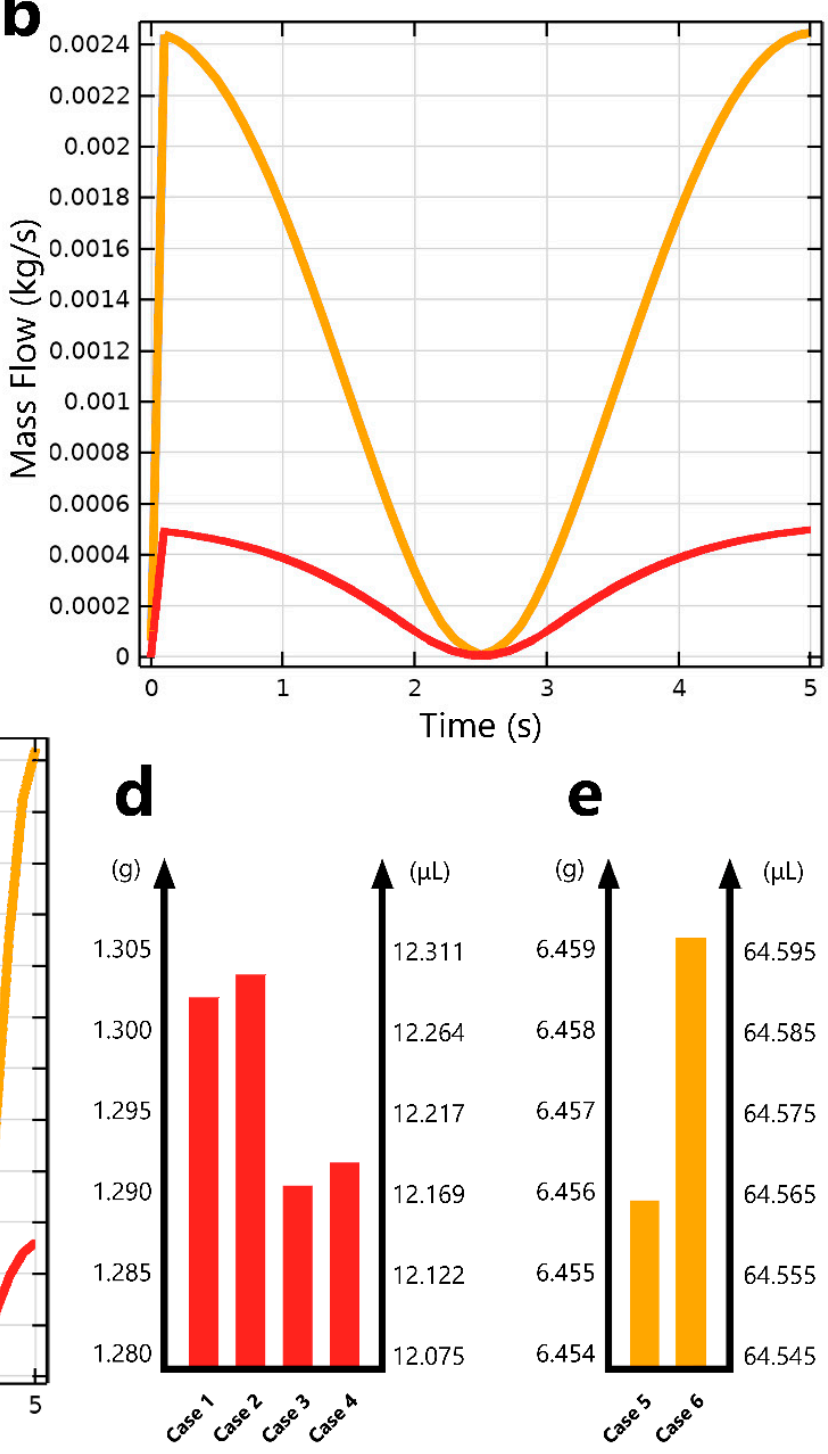
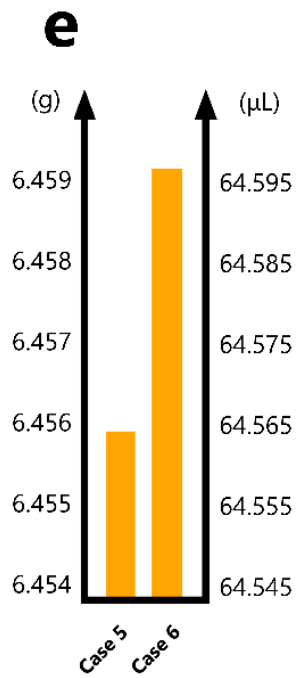

Figure 4. Mass flow-time curves at the reservoir and fluid extraction efficiency results. Two different fluids, human blood and interstitial fluid (ISF), with various boundary conditions (BCs) were used for simulation, which created a total of 6 different cases (organized in Table 3). (a) Representation of the device, and the referrals to the defined BCs. (b) The mass flow curve result at the reservoir for case 1 and case 5, presented in red and yellow, respectively. (c) The mass flow curve result at the reservoir for case 2 and case 6, presented in red and yellow, respectively. The curves at (b,c) show the mass flow rate in kg.s ${ }^{-1}$ for time in seconds for a duration of $5 \mathrm{~s}$. (d) Amounts of human blood extraction (cases 1 to 4), with the left vertical axis representing the total amount of the extracted human blood in grams, over a duration of $5 \mathrm{~s}$, and the right vertical axis representing the average amount of human blood extraction for each needle in microliters ( $\mu \mathrm{L}$ ) over a duration of 5 s. (e) Amounts of ISF extraction (cases 5 and 6), with the left vertical axis representing the total amount of the extracted ISF in grams over a duration of $5 \mathrm{~s}$, and the right vertical axis representing the average amount of ISF extraction for each needle in microliters $(\mu \mathrm{L})$ over a duration of $5 \mathrm{~s}$.

By integrating the area under the curves, we calculated the amount of the extracted fluid. Figure $4 \mathrm{~d}$ in the left vertical axis shows the total amount of the extracted blood in grams in $5 \mathrm{~s}$, with each line representing one of the four different criteria that were used for blood in the simulation (cases 1 to 4 in Table 3). The heartbeat-representing function simulations resulted in a lower amount of blood extraction, and pressing the button resulted in a subtle increase in the blood extraction amount. The device design included an MNA patch of $100 \mathrm{MNs}$, with each MN extracting the amounts in microliters 
$(\mu \mathrm{L})$ in $5 \mathrm{~s}$, as shown in the right vertical axis of Figure $4 \mathrm{~d}$. Among experimental setups of the MN devices for collecting blood samples, a study reported extraction of $4 \mu \mathrm{L}$ of mouse blood in vivo in $5 \mathrm{~s}$ per one needle [36]. Another study reported extraction of around $39 \mu \mathrm{L}$ rabbit blood in vivo per one needle in $5 \mathrm{~s}$ with a pre-vacuum system [53]. The results in the present work, with an average extraction of $12.24 \mu \mathrm{L}$ human blood in $5 \mathrm{~s}$ per needle, fall in the range of the experimentally reported cases.

For ISF extraction in two states of slow (case 5, Table 3) and fast (case 6, Table 3), the extraction amount slightly increased in fast mode (Figure 4e), with the left vertical axis for the total extracted ISF in grams in $5 \mathrm{~s}$. The MN patch included 100 needles. The average amount that each needle extracted in microliters in both states of slow and fast are represented in the right vertical axis of Figure 4e. The simulation resulted in an average extraction of $64.5 \mu \mathrm{L}$ ISF in $5 \mathrm{~s}$ per needle.

The simulation results for the amounts of ISF extraction, which was higher than previous reports, could be partially attributed to the mechanism of the extraction and the dissimilarities between the properties of the ISF of humans and animals. While the mechanism of ISF extraction in the majority of reports is on the basis of swellable materials, our design offers a high volume for fluid extraction rather than a limited volume of swellable needles. On the other hand, diffusion plays the main role in swelling, which is a slow procedure, requiring long durations of administration time such as a full day [66] or in some cases three weeks [49] to reach a meaningful result. In contrast, the device reported in this work is powered by finger pressure input, which not only offers a greater force for extraction in comparison with the naturally occurring diffusion, but also can be controlled very conveniently by pressing faster, enabling the extraction of ISF in higher volumes. Furthermore, as higher extraction rates are projected for human ISF compared to animal ISF [49], the dissimilarity between the properties of human and animal ISFs can be another reason for the extraction discrepancy. A previous research study on the extraction of ISF from mice has also stated that they anticipate a greater result in humans [49].

In addition, the extraction of ISF resulted in a higher efficiency when compared to the human blood (Figure 4). Since both the density and viscosity of ISF are lower than that of blood, the same finger pressure results in a greater extracted amount of ISF at the reservoir with less effort.

The simulation results for the presented cases in this work showed a successful extraction of the target fluid. One of the widely used components in microfluidic platforms is diode due to their capability of changing fluid direction on demand. Microfluidic diodes are a category of membranes that deform to an open shape in contact with the forward pressure of the flow, allowing the fluid to pass through the channel. Conversely, the diode closes when there is a backward fluid pressure, hence offering a great way for rectifying the flow $[67,68]$. Further studies on finger-powered microneedle research can benefit from the integration of diodes. For example, the utilization of microfluidic diodes was reported for a successful manipulation of the flow direction in a finger-powered microfluidic setup [55].

\section{Future Perspective and Conclusions}

Administration of new proactive healthcare procedures and technologies in medicine not only requires effective adoption by the society, but also well-informed framework to address any potential insecurity or anxiety concerns in patients, preventing any negative psychological effects $[69,70]$. Causing discomfort/pain or trypanophobia/needle phobia in patients, injection using traditional needles requires a trained healthcare worker, confining applicability of conventional needles in deprived regions or in-home treatments. One of the advantages that MNs and MNA-based devices offer in comparison to the conventional needle technologies is their solution for the fear of needles. A statistical study reported that 7 out of 10 children and 5 out of 10 adults are needle-phobic [71], which demonstrates the need for substituting devices offering painless injection procedures. On the other hand, MNs can be administrated by patients in the point-of-care settings (no need for healthcare workers) with minimal pain. An additional ability offered by MNs is the gradual release of 
substances for controlled drug delivery [72], promoting the potential applications of MNs for longer term treatments. Furthermore, microneedles can be integrated with biosignal acquisition techniques [7]. Therefore, MNs not only enable a minimally invasive injection experience, but they also can facilitate the development of wearable sensors [73] (with adherable MN patches) for continuous health monitoring, resulting in early diagnosis of disease, enhancing the success rate of therapies, decreasing healthcare costs, and ultimately promoting the wellbeing of the society. Hence, the acceptance and commercialization of MNs can be accelerated. In addition, in the last decade, many patents have been filed in MNs [74], indicating the high interest in this domain and their potential for a variety of drug delivery applications.

MNs, as an emerging technology, need to be translated from laboratory bench to commercial products. Fabrication methods that are used for manufacturing microfluidic devices and MNs are rapidly advancing to more cost-efficient procedures [75,76], leading to techniques that no longer require high-cost cleanroom facilities [77]. On the other hand, employment of mass producible manufacturing techniques (e.g., replica molding [78]) can reduce the overall production cost of MNs to have a competitive price with the conventional needles. In addition, in comparison to conventional needles that are usually made of stainless steel, MNs can be fabricated with low-cost materials such as polymers [74], lowering the final cost of the product, making MNs a more economical solution in biomedical applications [74]. For example, a cost-effectiveness analysis compared the utilization of MNs to conventional needles, reporting an estimation of USD 0.95 for MNs and USD 1.65 for conventional needles for the first dose of a vaccine delivery [79].

The process of sterilization of MNs prior to applying them into the skin requires high attention, especially in the presented setup, which is aimed to be used by the user or patient rather than a healthcare worker. Sterilization allows for preventing the transmission of bloodborne pathogens such as hepatitis B (HBV), hepatitis C (HCV), human immunodeficiency virus infection and acquired immunodeficiency syndrome (HIV / AIDS), malaria, and brucellosis. The materials for the fabrication of the MNs should be biocompatible to prevent any unwanted inflammations or allergies. Furthermore, for the case of blood collection, the extracted blood in the reservoir of the device is subject to undergo coagulation or erythrocyte aggregation if there is a long delay before analysis.

The concept of a finger-actuated device with integration of microneedle array (MNA) and a microfluidic chip was designed for extracting body fluid samples such as blood and ISF in a simple and fast manner. We simulated the process of extracting human blood from the body in different conditions. The simulation results demonstrated that our device was capable of extracting around $15.5 \mathrm{~g}$ of human blood in $1 \mathrm{~min}$. In addition, a second series of simulations demonstrated extraction of $77.4 \times 10^{3} \mu \mathrm{L}$ of ISF in $1 \mathrm{~min}$. 3D printing technologies, which are well known for printing both MNs and microfluidics chips, can also be utilized for fabrication of our device in a cost-efficient way. The ability to use a biocompatible material in 3D printing is another potential advantage for the fabrication of the device. With integration of personalized analysis tests and data processing, this device can be utilized in minimally invasive personalized medical equipment offering a simple usage procedure.

Supplementary Materials: The following are available online at https:/ /www.mdpi.com/article/10 $.3390 /$ app11125329/s1, Figure S1: Mass flow curve result at the reservoir for Case 3 in Table 3, and Figure S2: Mass flow curve result at the reservoir for Case 4 in Table 3.

Author Contributions: Conceptualization, S.T.; methodology, S.T. and M.R.S.; software, M.R.S. and A.A.; validation, M.R.S. and A.A.; formal analysis, M.R.S. and A.A.; writing-original draft preparation, M.R.S.; writing-review and editing, S.T. and A.K.Y.; supervision, S.T.; project administration, S.T.; funding acquisition, S.T. All authors have read and agreed to the published version of the manuscript.

Funding: S.T. acknowledges the Tubitak 2232 International Fellowship for Outstanding Researchers Award (118C391), Alexander von Humboldt Research Fellowship for Experienced Researchers, Marie 
Skłodowska-Curie Individual Fellowship (101003361), and the Royal Academy Newton-Katip Çelebi Transforming Systems Through Partnership award for their financial support of this research. This work was partially supported by Science Academy's Young Scientist Awards Program (BAGEP), Outstanding Young Scientists Awards (GEBIP), and Bilim Kahramanlari Dernegi The Young Scientist Award. Opinions, interpretations, conclusions, and recommendations are those of the author and are not necessarily endorsed by the TÜBİTAK.

Data Availability Statement: Data sharing not applicable.

Acknowledgments: We acknowledge Sajjad Rahmani Dabbagh for carefully reading our work and providing the authors with valuable feedback. The authors have no other relevant affiliations or financial involvement with any organization or entity with a financial interest in or financial conflict with the subject matter or materials discussed in the manuscript apart from those disclosed.

Conflicts of Interest: The authors declare no conflict of interest.

\section{References}

1. Gerstel, M.S.; Place, V.A. Drug Delivery Device. Google Patents US3964482A, 22 June 1976.

2. World Economic Forum Top 10 Emerging Technologies of 2020. Available online: www.weforum.org/reports/top-10-emergingtechnologies-2020 (accessed on 13 May 2021).

3. Chang, K.-T.; Shen, Y.-K.; Fan, F.-Y.; Lin, Y.; Kang, S.-C. Optimal design and fabrication of a microneedle arrays patch. J. Manuf. Process. 2020, 54, 274-285. [CrossRef]

4. Krieger, K.J.; Bertollo, N.; Dangol, M.; Sheridan, J.T.; Lowery, M.M.; O'Cearbhaill, E.D. Simple and customizable method for fabrication of high-aspect ratio microneedle molds using low-cost 3D printing. Microsyst. Nanoeng. 2019, 5, 1-14. [CrossRef]

5. Yokoyama, M.; Chihara, N.; Tanaka, A.; Katayama, Y.; Taruya, A.; Ishida, Y.; Yuzaki, M.; Honda, K.; Nishimura, Y.; Kondo, T.; et al. A biodegradable microneedle sheet for intracorporeal topical hemostasis. Sci. Rep. 2020, 10, 1-10. [CrossRef] [PubMed]

6. Chiappini, C.; De Rosa, E.; Martinez, J.O.; Liu, X.; Steele, J.R.; Stevens, M.M.; Tasciotti, E. Biodegradable silicon nanoneedles delivering nucleic acids intracellularly induce localized in vivo neovascularization. Nat. Mater. 2015, 14, 532-539. [CrossRef]

7. Dabbagh, S.R.; Sarabi, M.R.; Rahbarghazi, R.; Sokullu, E.; Yetisen, A.K.; Tasoglu, S. 3D-printed microneedles in biomedical applications. iScience 2021, 24, 102012. [CrossRef] [PubMed]

8. Cordeiro, A.S.; Tekko, I.; Jomaa, M.H.; Vora, L.; McAlister, E.; Volpe-Zanutto, F.; Nethery, M.; Baine, P.T.; Mitchell, N.; McNeill, D.W.; et al. Two-Photon Polymerisation 3D Printing of Microneedle Array Templates with Versatile Designs: Application in the Development of Polymeric Drug Delivery Systems. Pharm. Res. 2020, 37, 1-15. [CrossRef]

9. Kang, N.-W.; Kim, S.; Lee, J.-Y.; Kim, K.-T.; Choi, Y.; Oh, Y.; Kim, J.; Kim, D.-D.; Park, J.-H. Microneedles for drug delivery: Recent advances in materials and geometry for preclinical and clinical studies. Expert Opin. Drug Deliv. 2020. [CrossRef] [PubMed]

10. Yang, J.; Li, Y.; Ye, R.; Zheng, Y.; Li, X.; Chen, Y.; Xie, X.; Jiang, L. Smartphone-powered iontophoresis-microneedle array patch for controlled transdermal delivery. Microsyst. Nanoeng. 2020, 6, 1-14. [CrossRef]

11. Kusama, S.; Sato, K.; Matsui, Y.; Kimura, N.; Abe, H.; Yoshida, S.; Nishizawa, M. Transdermal electroosmotic flow generated by a porous microneedle array patch. Nat. Commun. 2021, 12, 1-11. [CrossRef]

12. Amer, R.I.; Elosaily, G.; Bakr, R.O.; Dine, R.S.E.; Fayez, A.M. Characterization and Pharmacological Evaluation of Anti-Cellulite Herbal Product(s) Encapsulated in 3D-Fabricated Polymeric Microneedles. Sci. Rep. 2020, 10, 1-16. [CrossRef]

13. Tran, K.T.M.; Gavitt, T.D.; Farrell, N.J.; Curry, E.J.; Mara, A.B.; Patel, A.; Brown, L.; Kilpatrick, S.; Piotrowska, R.; Mishra, N.; et al. Transdermal microneedles for the programmable burst release of multiple vaccine payloads. Nat. Biomed. Eng. 2020, 1-10. [CrossRef]

14. Zheng, M.; Wang, Z.; Chang, H.; Wang, L.; Chew, S.W.T.; Lio, D.C.S.; Cui, M.; Liu, L.; Tee, B.C.K.; Xu, C. Osmosis-Powered Hydrogel Microneedles for Microliters of Skin Interstitial Fluid Extraction within Minutes. Adv. Health Mater. 2020, 9, e1901683. [CrossRef]

15. Samant, P.P.; Niedzwiecki, M.M.; Raviele, N.; Tran, V.; Mena-Lapaix, J.; Walker, D.I.; Felner, E.I.; Jones, D.P.; Miller, G.W.; Prausnitz, M.R. Sampling interstitial fluid from human skin using a microneedle patch. Sci. Transl. Med. 2020, 12, eaaw0285. [CrossRef] [PubMed]

16. Wang, Z.; Luan, J.; Seth, A.; Liu, L.; You, M.; Gupta, P.; Rathi, P.; Wang, Y.; Cao, S.; Jiang, Q.; et al. Microneedle patch for the ultrasensitive quantification of protein biomarkers in interstitial fluid. Nat. Biomed. Eng. 2021, 5, 64-76. [CrossRef]

17. Frydman, G.H.; Olaleye, D.; Annamalai, D.; Layne, K.; Yang, I.; Kaafarani, H.M.A.; Fox, J.G. Manuka honey microneedles for enhanced wound healing and the prevention and/or treatment of Methicillin-resistant Staphylococcus aureus (MRSA) surgical site infection. Sci. Rep. 2020, 10,1-11. [CrossRef] [PubMed]

18. Li, W.; Terry, R.N.; Tang, J.; Feng, M.R.; Schwendeman, S.P.; Prausnitz, M.R. Rapidly separable microneedle patch for the sustained release of a contraceptive. Nat. Biomed. Eng. 2019, 3, 220-229. [CrossRef] [PubMed]

19. Jiang, X.; Lillehoj, P.B. Microneedle-based skin patch for blood-free rapid diagnostic testing. Microsyst. Nanoeng. 2020, 6, 1-11. [CrossRef] [PubMed] 
20. Xie, L.; Zeng, H.; Sun, J.; Qian, W. Engineering Microneedles for Therapy and Diagnosis: A Survey. Micromachines 2020, 11, 271. [CrossRef]

21. Yang, B.; Fang, X.; Kong, J. Engineered Microneedles for Interstitial Fluid Cell-Free DNA Capture and Sensing Using Iontophoretic Dual-Extraction Wearable Patch. Adv. Funct. Mater. 2020, 30, 2000591. [CrossRef]

22. Paul, R.; Saville, A.C.; Hansel, J.C.; Ye, Y.; Ball, C.; Williams, A.; Chang, X.; Chen, G.; Gu, Z.; Ristaino, J.B.; et al. Extraction of Plant DNA by Microneedle Patch for Rapid Detection of Plant Diseases. ACS Nano 2019, 13, 6540-6549. [CrossRef]

23. Moreira, A.F.; Rodrigues, C.F.; Jacinto, T.A.; Miguel, S.A.P.; Costa, E.C.; Correia, I.J. Microneedle-based delivery devices for cancer therapy: A review. Pharmacol. Res. 2019, 148, 104438. [CrossRef]

24. Ke, K.-H.; Chung, C.-K. High-Performance Al/PDMS TENG with Novel Complex Morphology of Two-Height Microneedles Array for High-Sensitivity Force-Sensor and Self-Powered Application. Small 2020, 16, 2001209. [CrossRef]

25. Sarabi, M.R.; Jiang, N.; Ozturk, E.; Yetisen, A.K.; Tasoglu, S. Biomedical optical fibers. Lab Chip 2021, 21, 627-640. [CrossRef]

26. Castilla-Casadiego, D.A.; Carlton, H.; Gonzalez-Nino, D.; Miranda-Muñoz, K.A.; Daneshpour, R.; Huitink, D.; Prinz, G.; Powell, J.; Greenlee, L.; Almodovar, J. Design, Characterization, and Modeling of a Chitosan Microneedle Patch for Transdermal Delivery of Meloxicam as a Pain Management Strategy for Use in Cattle. Mater. Sci. Eng. C 2021, 118, 111544. [CrossRef]

27. Loizidou, E.Z.; Inoue, N.T.; Ashton-Barnett, J.; Barrow, D.A.; Allender, C.J. Evaluation of geometrical effects of microneedles on skin penetration by CT scan and finite element analysis. Eur. J. Pharm. Biopharm. 2016, 107, 1-6. [CrossRef]

28. Rajeswari, N.R.; Malliga, P. Microfluidic system using microneedles for targeted drug delivery in cancer therapy. In Proceedings of the International Conference on Smart Structures and Systems-ICSSS'13, Institute of Electrical and Electronics Engineers (IEEE), Chennai, India, 28-29 March 2013; pp. 53-59.

29. Kanakaraj, U.; Lhaden, T.; Karthik, R.V. Analysis of structural mechanics of solid microneedle using COMSOL software. In Proceedings of the 2015 International Conference on Innovations in Information, Embedded and Communication Systems (ICIIECS), Coimbatore, India, 19-20 March 2015.

30. Rad, Z.F.; Nordon, R.; Anthony, C.J.; Bilston, L.; Prewett, P.D.; Arns, J.-Y.; Arns, C.H.; Zhang, L.; Davies, G.J. High-fidelity replication of thermoplastic microneedles with open microfluidic channels. Microsyst. Nanoeng. 2017, 3, 17034. [CrossRef]

31. Zoudani, E.; Soltani, M. A new computational method of modeling and evaluation of dissolving microneedle for drug delivery applications: Extension to theoretical modeling of a novel design of microneedle (array in array) for efficient drug delivery. Eur. J. Pharm. Sci. 2020, 150, 105339. [CrossRef] [PubMed]

32. Lee, K.J.; Jeong, S.S.; Roh, D.H.; Kim, D.Y.; Choi, H.-K.; Lee, E.H. A practical guide to the development of microneedle systems -In clinical trials or on the market. Int. J. Pharm. 2020, 573, 118778. [CrossRef]

33. Olatunji, O.; Das, D.B.; Garland, M.J.; Belaid, L.; Donnelly, R. Influence of Array Interspacing on the Force Required for Successful Microneedle Skin Penetration: Theoretical and Practical Approaches. J. Pharm. Sci. 2013, 102, 1209-1221. [CrossRef] [PubMed]

34. Davis, S.P.; Landis, B.J.; Adams, Z.H.; Allen, M.G.; Prausnitz, M.R. Insertion of microneedles into skin: Measurement and prediction of insertion force and needle fracture force. J. Biomech. 2004, 37, 1155-1163. [CrossRef] [PubMed]

35. Nicholas, D.; Logan, K.A.; Sheng, Y.; Gao, J.; Farrell, S.; Dixon, D.; Callan, B.; McHale, A.P.; Callan, J.F. Rapid paper based colorimetric detection of glucose using a hollow microneedle device. Int. J. Pharm. 2018, 547, 244-249. [CrossRef]

36. Li, C.G.; Lee., C.Y.; Lee, K.; Jung, H. An optimized hollow microneedle for minimally invasive blood extraction. Biomed. Microdevices 2013, 15, 17-25. [CrossRef]

37. Zhu, J.; Zhou, X.; Kim, H.-J.; Qu, M.L.; Jiang, X.; Lee, K.; Ren, L. Gelatin methacryloyl microneedle patches for minimally invasive extraction of skin interstitial fluid. Small 2020, 16, 1905910. [CrossRef]

38. Yao, W.; Li, D.; Zhao, Y.; Zhan, Z.; Jin, G.; Liang, H.; Yang, R. 3D Printed Multi-Functional Hydrogel Microneedles Based on High-Precision Digital Light Processing. Micromachines 2019, 11, 17. [CrossRef] [PubMed]

39. Taylor, R.M.; Maharjan, D.; Moreu, F.; Baca, J.T. Parametric study of 3D printed microneedle (MN) holders for interstitial fluid (ISF) extraction. Microsyst. Technol. 2020, 26, 2067-2073. [CrossRef] [PubMed]

40. Takeuchi, K.; Takama, N.; Kim, B.; Sharma, K.; Paul, O.; Ruther, P. Microfluidic chip to interface porous microneedles for ISF collection. Biomed. Microdevices 2019, 21, 28. [CrossRef] [PubMed]

41. Miller, P.R.; Taylor, R.M.; Tran, B.Q.; Boyd, G.; Glaros, T.; Chavez, V.H.; Krishnakumar, R.; Sinha, A.; Poorey, K.; Williams, K.P.; et al. Extraction and biomolecular analysis of dermal interstitial fluid collected with hollow microneedles. Commun. Biol. 2018, 1, 1-11. [CrossRef]

42. Caffarel-Salvador, E.; Brady, A.J.; Eltayib, E.; Meng, T.; Alonso-Vicente, A.; Gonzalez-Vazquez, P.; Torrisi, B.M.; Vicente-Perez, E.M.; Mooney, K.; Jones, D.S.; et al. Hydrogel-Forming Microneedle Arrays Allow Detection of Drugs and Glucose In Vivo: Potential for Use in Diagnosis and Therapeutic Drug Monitoring. PLoS ONE 2015, 10, e0145644. [CrossRef]

43. Fonseca, D.F.S.; da Costa, P.J.C.; Almeida, I.F.; Dias-Pereira, P.; Correia-Sá, I.; Bastos, V.; Oliveira, H.; Vilela, C.; Silvestre, A.J.D.; Freire, C.S.R. Swellable Gelatin Methacryloyl Microneedles for Extraction of Interstitial Skin Fluid toward Minimally Invasive Monitoring of Urea. Macromol. Biosci. 2020, 20, e2000195. [CrossRef]

44. Sulaiman, D.A.; Chang, J.Y.H.; Bennett, N.R.; Topouzi, H.; Higgins, C.A.; Irvine, D.J.; Ladame, S. Hydrogel-Coated Microneedle Arrays for Minimally Invasive Sampling and Sensing of Specific Circulating Nucleic Acids from Skin Interstitial Fluid. ACS Nano 2019, 13, 9620-9628. [CrossRef]

45. Chen, J.; Wang, M.; Ye, Y.; Yang, Z.; Ruan, Z.; Jin, N. Fabrication of sponge-forming microneedle patch for rapidly sampling interstitial fluid for analysis. Biomed. Microdevices 2019, 21, 63. [CrossRef] 
46. Kolluru, C.; Williams, M.; Chae, J.; Prausnitz, M.R. Recruitment and Collection of Dermal Interstitial Fluid Using a Microneedle Patch. Adv. Health Mater. 2019, 8, e1801262. [CrossRef]

47. Samant, P.P.; Prausnitz, M.R. Mechanisms of sampling interstitial fluid from skin using a microneedle patch. Proc. Natl. Acad. Sci. USA 2018, 115, 4583-4588. [CrossRef] [PubMed]

48. Taylor, R.M.; Miller, P.R.; Ebrahimi, P.; Polsky, R.; Baca, J.T. Minimally-invasive, microneedle-array extraction of interstitial fluid for comprehensive biomedical applications: Transcriptomics, proteomics, metabolomics, exosome research, and biomarker identification. Lab Anim. 2018, 52, 526-530. [CrossRef] [PubMed]

49. Chang, H.; Zheng, M.; Yu, X.; Than, A.; Seeni, R.Z.; Kang, R.; Tian, J.; Khanh, D.P.; Liu, L.; Chen, P.; et al. A Swellable Microneedle Patch to Rapidly Extract Skin Interstitial Fluid for Timely Metabolic Analysis. Adv. Mater. 2017, 29, 1702243. [CrossRef] [PubMed]

50. Mishra, R.K.; Mohan, A.M.V.; Soto, F.; Chrostowski, R.; Wang, J. A microneedle biosensor for minimally-invasive transdermal detection of nerve agents. Analyst 2017, 142, 918-924. [CrossRef]

51. Zhang, X.; Chen, G.; Bian, F.; Cai, L.; Zhao, Y. Encoded microneedle arrays for detection of skin interstitial fluid biomarkers. Adv. Mater. 2019, 31, 1902825. [CrossRef] [PubMed]

52. He, R.; Niu, Y.; Li, Z.; Li, A.; Yang, H.; Xu, F.; Li, F. A Hydrogel Microneedle Patch for Point-of-Care Testing Based on Skin Interstitial Fluid. Adv. Health Mater. 2020, 9, e1901201. [CrossRef]

53. Li, C.G.; Dangol, M.; Lee, C.Y.; Jang, M.; Jung, H. A self-powered one-touch blood extraction system: A novel polymer-capped hollow microneedle integrated with a pre-vacuum actuator. Lab Chip 2015, 15, 382-390. [CrossRef]

54. Li, C.G.; Lee, K.; Lee, C.Y.; Dangol, M.; Jung, H. A Minimally Invasive Blood-Extraction System: Elastic Self-Recovery Actuator Integrated with an Ultrahigh- Aspect-Ratio Microneedle. Adv. Mater. 2012, 24, 4583-4586. [CrossRef]

55. Iwai, K.; Shih, K.C.; Lin, X.; Brubaker, T.A.; Sochol, R.D.; Lin, L. Finger-powered microfluidic systems using multilayer soft lithography and injection molding processes. Lab Chip 2014, 14, 3790-3799. [CrossRef] [PubMed]

56. Hund, S.J.; Kameneva, M.V.; Antaki, J.F. A Quasi-Mechanistic Mathematical Representation for Blood Viscosity. Fluids 2017, 2, 10. [CrossRef]

57. Sequeira, A.; Janela, J. An overview of some mathematical models of blood rheology. In A Portrait of State-of-the-Art Research at the Technical University of Lisbon; Springer: Dordrecht, The Netherlands, 2007; pp. 65-87. [CrossRef]

58. Klarhöfer, M.; Csapo, B.; Balassy, C.; Szeles, J.; Moser, E. High-resolution blood flow velocity measurements in the human finger. Magn. Reson. Med. 2001, 45, 716-719. [CrossRef]

59. Ahlborg, G.; Jensen-Urstad, M. Arm blood flow at rest and during arm exercise. J. Appl. Physiol. 1991, 70, 928-933. [CrossRef]

60. Netea, R.T.; Lenders, J.W.M.; Smits, P.; Thien, T. Both body and arm position significantly influence blood pressure measurement. J. Hum. Hypertens. 2003, 17, 459-462. [CrossRef]

61. Ostchega, Y.; Porter, K.S.; Hughes, J.; Dillon, C.F.; Nwankwo, T. Resting Pulse Rate Reference Data for Children, Adolescents, and Adults: United States, 1999-2008; US Department of Health and Human Services, Centers for Disease Control and Prevention, National Center for Health Statistics: Atlanta, GA, USA, 2011.

62. Jose, A.D.; Collison, D. The normal range and determinants of the intrinsic heart rate in man. Cardiovasc. Res. 1970, 4, 160-167. [CrossRef]

63. Ebah, L. Extraction and Analysis of Interstitial Fluid, and Characterisation of the Interstitial Compartment in Kidney Disease. Ph.D. Thesis, The University of Manchester, Manchester, UK, 2012. Available from ProQuest Dissertations with ID No. 1774233691.

64. Yao, W.; Li, Y.; Ding, G. Interstitial Fluid Flow: The Mechanical Environment of Cells and Foundation of Meridians. Evidence-Based Complement. Altern. Med. 2012, 2012, 1-9. [CrossRef]

65. Aukland, K.; Reed, R.K. Interstitial-lymphatic mechanisms in the control of extracellular fluid volume. Physiol. Rev. 1993, 73, 1-78. [CrossRef]

66. Donnelly, R.F.; McCrudden, M.T.C.; Alkilani, A.Z.; Larrañeta, E.; McAlister, E.; Courtenay, A.J.; Kearney, M.-C.; Singh, T.R.R.; McCarthy, H.O.; Kett, V.; et al. Hydrogel-Forming Microneedles Prepared from "Super Swelling" Polymers Combined with Lyophilised Wafers for Transdermal Drug Delivery. PLoS ONE 2014, 9, e111547. [CrossRef]

67. Adams, M.L.; Johnston, M.L.; Scherer, A.; Quake, S.R. Polydimethylsiloxane based microfluidic diode. J. Micromech. Microeng. 2005, 15, 1517-1521. [CrossRef]

68. Grover, W.H.; Skelley, A.M.; Liu, C.N.; Lagally, E.T.; Mathies, R.A. Monolithic membrane valves and diaphragm pumps for practical large-scale integration into glass microfluidic devices. Sens. Actuators B Chem. 2003, 89, 315-323. [CrossRef]

69. Safi, S.; Thiessen, T.; Schmailzl, K.J. Acceptance and Resistance of New Digital Technologies in Medicine: Qualitative Study. JMIR Res. Protoc. 2018, 7, e11072. [CrossRef]

70. Paré, G.; Sicotte, C.; Jacques, H. The Effects of Creating Psychological Ownership on Physicians' Acceptance of Clinical Information Systems. J. Am. Med. Inform. Assoc. 2006, 13, 197-205. [CrossRef] [PubMed]

71. Kettwich, S.C.; Sibbitt, W.L.; Brandt, J.R.; Johnson, C.R.; Wong, C.S.; Bankhurst, A.D. Needle Phobia and Stress-Reducing Medical Devices in Pediatric and Adult Chemotherapy Patients. J. Pediatr. Oncol. Nurs. 2007, 24, 20-28. [CrossRef]

72. Nagarkar, R.; Singh, M.; Nguyen, H.X.; Jonnalagadda, S. A review of recent advances in microneedle technology for transdermal drug delivery. J. Drug Deliv. Sci. Technol. 2020, 59, 101923. [CrossRef]

73. Teymourian, H.; Tehrani, F.; Mahato, K.; Wang, J. Lab under the Skin: Microneedle Based Wearable Devices. Adv. Health Mater. 2021, 2002255. [CrossRef] 
74. Ali, R.; Mehta, P.; Arshad, M.S.; Kucuk, I.; Chang, M.-W.; Ahmad, Z. Transdermal Microneedles-A Materials Perspective. AAPS PharmSciTech 2019, 21, 12. [CrossRef] [PubMed]

75. Faustino, V.; Catarino, S.O.; Lima, R.; Minas, G. Biomedical microfluidic devices by using low-cost fabrication techniques: A review. J. Biomech. 2016, 49, 2280-2292. [CrossRef]

76. Johnson, A.R.; Procopio, A.T. Low cost additive manufacturing of microneedle masters. 3D Print. Med. 2019, 5, 1-10. [CrossRef]

77. Nejad, H.R.; Sadeqi, A.; Kiaee, G.; Sonkusale, S. Low-cost and cleanroom-free fabrication of microneedles. Microsyst. Nanoeng. 2018, 4, 17073. [CrossRef]

78. Park, Y.-H.; Ha, S.K.; Choi, I.; Kim, K.S.; Park, J.; Choi, N.; Kim, B.; Sung, J.H. Fabrication of degradable carboxymethyl cellulose (CMC) microneedle with laser writing and replica molding process for enhancement of transdermal drug delivery. Biotechnol. Bioprocess. Eng. 2016, 21, 110-118. [CrossRef]

79. Adhikari, B.B.; Goodson, J.L.; Chu, S.Y.; Rota, P.A.; Meltzer, M.I. Assessing the Potential Cost-Effectiveness of Microneedle Patches in Childhood Measles Vaccination Programs: The Case for Further Research and Development. Drugs RED 2016, 16, 327-338. [CrossRef] 